\title{
BIOGAS PRODUCTION FROM AGROWASTE AND EFFLUENTS
}

\author{
Marlia M. Hanafiah'1, Mohamed Yasreen M. Ali', Nur Izzah Hamna A. Aziz' ${ }^{1}$, Akbar John² \\ ${ }^{1}$ School of Environmental and Natural Resource Sciences, Faculty of Science and Technology, Universiti Kebangsaan Malaysia, 43600 Bangi, \\ Selangor, Malaysia
}

${ }^{2}$ INOCEM Research Station (IRS), Department of Biotechnology, Kulliyyah of Science, International Islamic University Malaysia (IIUM), Kuantan, Pahang, International Islamic University Malaysia (IIUM), Kuantan, Pahang

*Corresponding author e-mail: mhmarlia@ukm.edu.my

This is an open access article distributed under the Creative Commons Attribution License, which permits unrestricted use, distribution, and reproduction in any medium, provided the original work is properly cited.

\begin{tabular}{|c|c|}
\hline ARTICLE DETAILS & ABSTRACT \\
\hline $\begin{array}{l}\text { Article History: } \\
\text { Received } 12 \text { August } 2016 \\
\text { Accepted } 12 \text { December } 2016 \\
\text { Available online } 17 \text { february } 2017\end{array}$ & $\begin{array}{l}\text { One of the alternative sources for clean energy is biogas. Generating energy from agrowaste and effluents can lessen } \\
\text { environmental impacts. This study was conducted to determine the production of biogas from six potential } \\
\text { substrates, i.e. goat dung (GD), chicken dung (CD), fish waste (FW), rice waste (RW), palm oil mill effluent (POME) } \\
\text { and sewage sludge (SS) using industrial inoculum as catalysts. Biophysical characteristics were assessed using } \\
\text { laboratory-based analyses, whereas the Bio-Methane Potential (BMP) assay was used to measure anaerobic biogas } \\
\text { production in mesophilic condition for } 20 \text { consecutive days. Results revealed that rice waste with industrial } \\
\text { inoculum produces the highest amount of biogas, followed by goat dung, chicken dung, fish waste, palm oil mill } \\
\text { effluent and sewage sludge with total amount of } 3508.9 \mathrm{~mL}, 2141 \mathrm{~mL}, 1885.7 \mathrm{~mL}, 1546.0 \mathrm{~mL}, 743.8 \mathrm{~mL} \text { and } 547.7 \\
\text { mL, respectively. In conclusion, all substrates used in this study can be combined with industrial inoculum would } \\
\text { serve producing energy in a small-scale industry. }\end{array}$ \\
\hline
\end{tabular}

\section{KEYWORDS}

Bio-methane potential, Biogas production, Inoculum, Agrowaste, Effluents, Malaysia.

\section{INTRODUCTION}

Biogas is a mixture of methane gas ( $\mathrm{CH} 4)$ with composition of $40 \%$ to $70 \%$, carbon dioxide gas (CO2) with $25 \%$ to $40 \%$, hydrogen gas (H2) with less than one part per millions ( $\mathrm{ppm})$, nitrogen $(<3 \mathrm{ppm})$ and hidrogen sulphide (H2S) is $(<10 \mathrm{ppm})$ forms from the decomposition of organics through the anaerobic digestion. Biogas is obtained through decomposition process of organic material consisting of several stages; hydrolysis, acidogenesis, acetogenesis and methanogenesis. Each stage requires different anaerobic bacteria such as Lactobacillus sp., Clostridium sp., Methanobacter sp. and Aminobacterium sp. to decompose the organic materials into methane gas. Residues obtained from harvesting and milling agricultural production can be utilised as fuel for energy generation [1,2]. Biomass in Malaysia contributes about $14 \%$ of the approximately 340 million barrels of oil equivalent (boe) of energy used every year and wood products, palm oil mill effluents, goat dung, chicken dung, fish waste, etc., are extensively utilised. Wastes particularly from livestock's, palm oil effluents and food contribute to the environmental pollution to air, soil and water. High remains from animal manure causing water and odour pollution due to the high content of ammonia (NH3) and hydrogen sulphide (H2S) in the manure [3].This paper determines the biophysical characteristics of six potential wastes, i.e. goat dung (GD), chicken dung (CD), Palm Oil Mill Effluent (POME), sewage sludge (SS), rice waste (RW) and fish waste (FW). The productions of biogas from six substrates using inoculum as catalyst were measured. The anaerobic biogas production was measured in mesophilic condition for 20 consecutive days using a Bio-Methane Potential (BMP) assay

\section{METHODOLOGY}

In this paper, six substrates were collected from several farms, factory and premises located in Malaysia. The goat dung and chicken dung were weighted for $3 \mathrm{~kg}$ each and packed in airtight plastic bags to make sure the samples were mixed well. POME was sampled using a litre capacity of Schott bottle from the pipe that drained the POME to the treatment ponds. The sewage sludge was collected from the drain pipe of sewage sludge to the sludge digestion tank containing sewage mixture from primary and secondary clarifications.

The rice waste was sampled at restaurants nearby and the rice waste was separated from other wastes prior the sampling. The fish waste was collected from fishmonger at the wet market. The initial $\mathrm{pH}$ and temperature of all substrates were recordedBiophysical characteristics of the six substrates such as temperature, $\mathrm{pH}$, Chemical Oxygen Demand (COD) and metal concentrations ( $\mathrm{Ca}, \mathrm{Li}, \mathrm{Mg}$ ) were determined. For BioMethane Potential Test, nitrogen gas is channelled through vulcanised rubber pipe to the digester bottles to ensure no oxygen trapped inside the digester bottles and to maintain the anaerobic conditions inside the digester bottles. The BMP has several components such as water bath machine, eudiometer tubes, beakers, glass Schott bottles, connector tubes and nitrogen gas tank.

\section{RESULTS AND DISCUSSION}

The biophysical characteristics of six substrates are shown in Table 1. Temperature is crucial in anaerobic fermentation especially during hydrolysis and methanogenesis process. Low temperature reduced the microbe's growth rate and lead to the lower rate of biogas production [4]. However, high temperature will also lower the biogas productions as high temperature will trigger the production of ammonia gas that retarded the methanogenic activity [5]. Mesophilic and thermophilic temperatures are the optimum condition for gas production. The mesophilic bacteria thrive in a temperature ranges between $30^{\circ} \mathrm{C}$ to $37^{\circ} \mathrm{C}$ and thermophilic bacteria thrive are active in temperature ranges of $50^{\circ} \mathrm{C}$ to $65^{\circ} \mathrm{C}$. Thermophilic temperature produces more biogas and quicker than mesophilic temperature yet the biogas produced is not worth the energy needed to maintain and raise the digester temperature from $37^{\circ} \mathrm{C}$ to $50^{\circ} \mathrm{C}$. While mesophilic temperature is more stable and require less energy for the anaerobic decomposition operation. In addition, mesophilic bacteria may tolerate with drastic changes in surrounding including the temperature [6]. 
Table 1: Biophysical characteristics of six substrates

\begin{tabular}{lcccccc}
\hline \multicolumn{1}{c}{ Parameters } & GD & CD & POME & SS & RW & FW \\
\hline pH & 7.74 & 7.79 & 7.85 & 8.51 & 7.66 & 7.78 \\
COD & $1.93 \pm$ & $2.80 \pm$ & $0.57 \pm$ & $0.33 \pm$ & $0.46 \pm$ & $0.26 \pm$ \\
& 0.06 & 0.14 & 0.01 & 0.02 & 0.03 & 0.09 \\
Metals (mg/L) & & & & & & \\
Calcium (Ca) & 14.80 & 10.50 & 1.17 & 1.23 & 1.02 & 1.63 \\
Lithium (Li) & 0.21 & 0.21 & ud & ud & 0.21 & 0.21 \\
Magnesium & $\underline{8.10}$ & $\underline{5.53}$ & $\underline{1.54}$ & $\underline{0.24}$ & 0.03 & 0.50 \\
$\underline{(M g)}$ & & & & & & \\
\cline { 2 - 3 } & & & & & &
\end{tabular}

All parameters are in $\mathrm{g} \mathrm{L}-1$ except for $\mathrm{pH}$ and heavy metals

$*_{-=\text {No test conducted }}$

*ud=Undetected

The $\mathrm{pH}$ value affects the microorganism's growth during the anaerobic digestion and microorganisms need neutral to alkaline medium $\mathrm{(pH} 6.8$ 8.5) for methane production [7]. Although $\mathrm{pH}$ recorded for GD and POME were too alkaline and slightly acidic, however inoculum provides an optimum $\mathrm{pH}$ for the substrates decomposition. The optimum $\mathrm{pH}$ value is varying in acidogenesis and methanogenesis process. During hydrolysis and acetogenesis process, the $\mathrm{pH}$ is usually 5.5 and 6.5 , respectively. Productions of acetic acid, lactic acid and propionic acid during acidogenesis process cause the $\mathrm{pH}$ to decrease. The methanogenic bacteria's growth is sensitive in an acidic medium and may retard the growth of the methanogenic bacteria [8].

COD test was done to determine how many grams of oxygen used by a litre of substrate. Organic elements undergo oxidation to carbon dioxide and water in acidic medium. CD produced 0.98 litre of methane gas as COD of $\mathrm{CD}$ is the highest among the other substrates. Theoretically, organic matter consists of carbon $(\mathrm{C})$, hydrogen $(\mathrm{H})$ and oxygen $(\mathrm{O})$ fully oxidised to carbon dioxide ( $\mathrm{CO} 2)$ and water (H2O). The COD test could estimate overall production of methane gas produced by the substrates with $1 \mathrm{~g}$ COD can produce $0.35 \mathrm{~L}$ of methane gas.

Table 1 also indicates the heavy metal contents of the substrates. The highest calcium content was found in CD with $10.50 \mathrm{~g} / \mathrm{L}$ compared to other substrates with less than $1.65 \mathrm{~g} / \mathrm{L}$. The calcium increases the rate of organic decomposition. Calcium concentration of more than $0.3 \mathrm{~g} / \mathrm{L}$ is beneficial for the production of biogas and calcium concentration up to 70 $\mathrm{g} / \mathrm{L}$ do not result any negative impact on biogas production [9]. GD contained the highest $\mathrm{Mg}$ content with $8.10 \mathrm{~g} / \mathrm{L}$ followed by CD with 5.53 g/L. RW and FW have the lowest Mg content with 0.03 and 0.51 , respectively. Mg shortened the time for substrate to decompose and increased the biogas production with the Mg content of more than 0.03 $\mathrm{g} / \mathrm{L}$ up to $0.2 \mathrm{~g} / \mathrm{L}$. However, the Mg content more than $10 \mathrm{~g} / \mathrm{L}$ will retard the biogas production. Lithium (Li) was undetected in POME, SS, RW and FW and was found in GD and CD with $0.21 \mathrm{~g} / \mathrm{L}$ in both substrates. Li is easy to be detected in biogas slurries and the concentration of $\mathrm{Li}$ in GD and $\mathrm{CD}$ has no negative effects on the biogas digestion. The present of heavy metal's cations such as $\mathrm{Na}+, \mathrm{Ca} 2+$ and $\mathrm{Mg} 2+$ give an antagonistic effect to reduce ammonia concentration. This is due to the toxicity level of ions reduced with the present of other ions. In an average concentration, heavy metals will trigger the growth of the anaerobic bacteria. High concentration of heavy metals cause toxicity as the increase in osmotic pressure and hydrolysed the microorganisms cell. Heavy metals will cause toxicity if in a free solubility condition.

Bio-Methane Potential (BMP) Test was used to identify the amount of biogas produced from decomposed organic material from the digester through anaerobic decomposition. Although has been criticised for its time-consuming process which is an average of 20 days to 30 days, the BMP test is simple to conduct and reproducible. The 20 days period needed because the colonised bacteria in the digester bottles will function effectively in these time [10].

Figure 1 illustrates the percentages of methane production from six substrates using industrial inoculum. CD produced $30.2 \%$ of methane due to high COD implying high organic content in the CD, whereas the lowest percentage of methane was produced by FW $(17.7 \%)$.

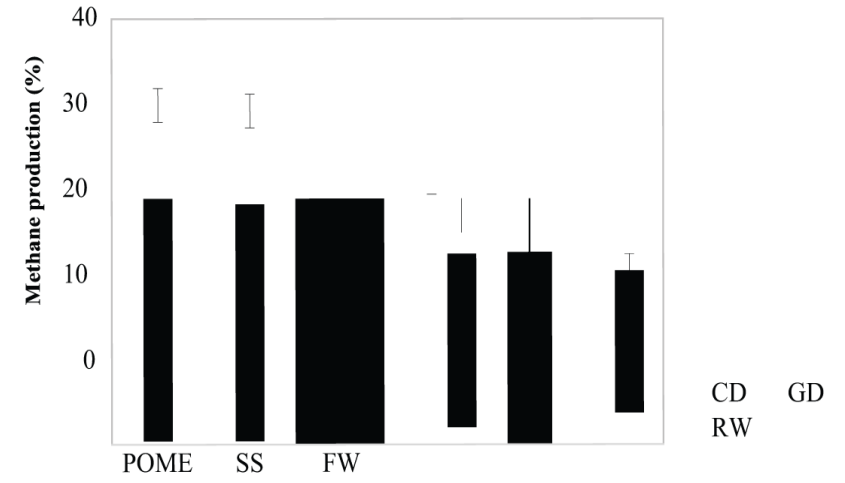

Figure 1: Methane production (\%) from CD, GD, RW, POME, SS and FW using industrial inoculum

Graph of cumulative daily biogas production for 20 consecutive days from six different substrates using industrial inoculum can be found in the Figure 2. By using industrial inoculum, RW produced the highest amount of biogas $(3,508.87 \mathrm{~mL})$, followed by GD $(2,141.00 \mathrm{~mL}), \mathrm{CD}(1,885.70 \mathrm{~mL})$, FW $(1,546.00 \mathrm{~mL})$, POME $(740.00 \mathrm{~mL})$ and SS $(550.00 \mathrm{~mL})$. RW contained of high concentration of carbohydrates and calcium. Although FW has high amounts of $\mathrm{Ca}$ and $\mathrm{Mg}$, the nutrient content of $\mathrm{FW}$ is low thus produces lower amount of biogas [11]. Main purpose of anaerobic treatment is to reduce mass content. Inoculum is proven as a catalyst to increase the anaerobic process performance with increasing the quantity of anaerobic's bacteria that enhanced the degradation of organic substance degradation in the substrates. Adding inoculum inside the digester will decrease time for bio stabilization that can increase the methane gas production. Generally, inoculum is produced from sewage waste treatment station or materials from animal sources such as cow manure, chicken manure and other manures containing microorganisms [12].

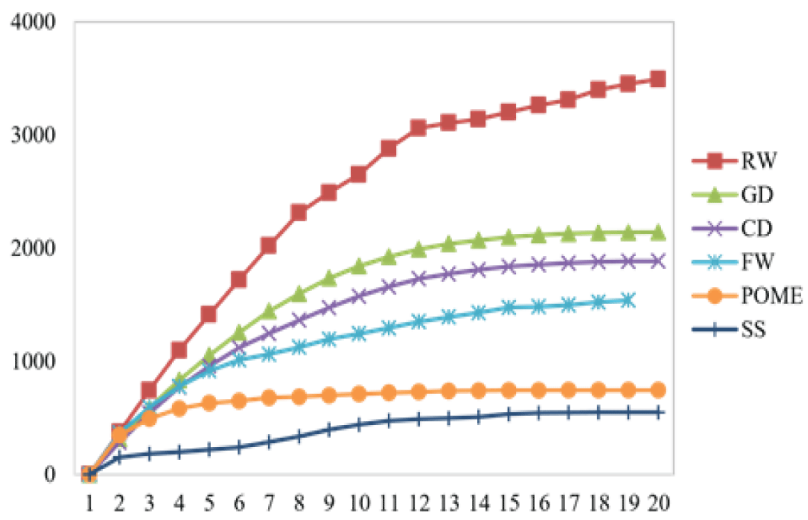

Time (Day)

Figure 2: Cumulative of daily biogas production from RW, GD, CD, FW, POME and SS using industrial inoculum $(\mathrm{mL})$

\section{CONCLUSION}

In conclusion, agrowaste with industrial inoculum produced high biogas concentration and effective in producing methane gas. However, strong consideration should be given to the substrate being used for biogas production as different stage of vegetation from agro wastes and different feed being employed to rear cattle has considerable impact on the amount and quality of biogas being produced. Optimum biogas harvest time using different substrates with industrial inoculum was also addressed which will be crucial for small scale industry to achieve optimum biogas and biomethane yield in short time period. The limitation of this study includes the pilot design of the digester container itself as it might end up in leakage of gas and liquids.

\section{ACKNOWLEDGEMENT}

We acknowledge the use of facilities within the Tasik Chini Research Centre (PPTC), UKM. We thank Yeong Hui Wen and Nur Fatin Baharudin for helping us with the analyses. Marlia Mohd Hanafiah was financed by research grants: FRGS/2/2013/STWN01/UKM/03/1 and TD-2014-012. 


\section{REFERENCES}

[1] Klass, D. L. 2004. Biomass for Renewable Energy and Fuels. Encyclopedia of Energy, 1(1), 212-193.

[2] Nagy, V., \& Szabó, E. 2011. Biogas from Organic Wastes. Studia Universitatis Vasile Goldis Arad, Seria Stiintele Vietii, 21(4),

[3] Oyewole, O. A. 2010. Biogas Production from Chicken Droppings. Science World Journal, 5(4), 11-14.

[4] Karakashev , D . , Batstone , D . J . , \& Angelidaki, I . 2005. Influence of Environmental Conditions on Methanogenic Compositions in Anaerobic Biogas Reactors. Applied and environmental microbiology, 71(1), 331338.

[5] Chen ,X,Yan ,W.,Sheng ,K.,\&Sanati, M 2014. Comparison of High-Solids to Liquid Anaerobic CoDigestion of Food Waste and Green Waste. Bioresource Technology, 154, 215-221.

[6] Nayono, S.E., Gallert C. , \& Winter, J .2010 . Co-digestion of press water and food waste in a biowaste digester for =improvement of biogas production. Bioresource Technology, 101, 6987-6993.
[7] Hong ,Z . ,Deng, G ., \& Li' an, G . 2008 . Research on the Effect of pH for Biogas Production. Journal of Anhui Agricultural Sciences, 19, 114

[9] Abbasi, T ., Tauseef, S . M., \& Abbasi, S. A. 2012. Anaerobic Digestion for Global Warming Control and Energy Generationan Overview. Renewable and Sustainable Energy Reviews, $\quad$ 16(5),3228-3242.

[10] Martens, E . C. , Heungens , K . , \& Goodrich-Blair, H . 2003. Early Colonization Events in the Mutualistic Association between Steinernema Carpocapsae Nematodes and Xenorhabdus Nematophila Bacteria. Journal of Bacteriology, 185(10), 3147-3154.

[11] Lopes, W. S. , Leite, V. D. , \& Prasad, S.2004. Influence of inocuum on perfomance of anaerobic reactors for treating municipal solid waste. Bioresource Technology, 94(3),261-266.

[12] Hanafiah, M. M., Mohamed Ali, M. Y., Abdul Aziz, N. I. H., Ashraf, M. A., Halim, A. A., Lee, K. E., \& Idris, M. 2017. Biogas Production from Goat and Chicken Manure in Malaysia. Applied ecology and Environmental Research,15(3),529-535 